\title{
Help Spain by showing films. British film production for humanitarian aid during the Spanish Civil War
}

\author{
Laura López-Martín \\ Universidad Rey Juan Carlos \\ e-mail: laura.lopez@urjc.es \\ ORCID iD: http://orcid.org/0000-0003-1532-5134
}

Submitted: 18 May 2018. Accepted: 22 June 2019

\begin{abstract}
The Spanish Civil War mobilised a wide spectrum of the British population, a mood which materialised in the despatch of humanitarian aid, mainly to republican Spain. To this end, there were meetings and rallies in which the use of film was customary. Films made it possible to show a different reality from that which appeared on the newsreels, provided an opportunity for fund-raising and showed the deployment and results of the aid received. The distribution of the films, and occasionally their production, was undertaken by progressive film organisations, close to the Communist party, which raised doubts vis-à-vis the real intentions of the humanitarian organisations.
\end{abstract}

KEYWORDS: Refugees; Children; Great Britain; Cinematography; Propaganda; Aid; Solidarity.

Citation / Cómo citar este artículo: López-Martín, Laura (2019) "Help Spain by showing films. British film production for humanitarian aid during the Spanish Civil War". Culture \& History Digital Journal, 8 (2): e019. https://doi.org/10.3989/ chdj.2019.019

RESUMEN: Help Spain by showing films. Producción cinematográfica británica para la ayuda humanitaria durante la Guerra Civil Española.- La Guerra Civil española movilizó a un amplio espectro de la población británica que se tradujo en el envío de ayuda humanitaria, principalmente a la España republicana. Para ello, se realizaron mítines y reuniones en los que el uso del cine fue habitual. El cine permitió mostrar una realidad diferente a la que aparecía en los noticiarios cinematográficos, posibilitó la recaudación de fondos y mostró el funcionamiento y resultado de la ayuda prestada. La distribución de las películas, y ocasionalmente su realización, estuvo en manos de organizaciones cinematográficas progresistas, cercanas al partido al comunista, lo cual sembró dudas sobre las intenciones reales de las organizaciones humanitarias.

PALABRAS CLAVE: Refugiados; Niños; Gran Bretaña; Cinematografía; Propaganda; Ayuda; Solidaridad.

Copyright: (C 2019 CSIC. This is an open-access article distributed under the terms of the Creative Commons Attribution 4.0 International (CC BY 4.0) License. 


\section{INTRODUCTION}

British participation in the Spanish Civil War began shortly after the military uprising. The Socialist Medical Association, assembled on August 8, 1936 at the Trade Union Club, decided to set up a Medical Unit to be sent to Spain immediately. The unit was named the British Medical Unit for Spain, the committee Spanish Medical Aid Committee (SMAC) and enjoyed the collaboration of the Independent Labour Party (McNair, 1936: 16) and the Trades Union Congress (TUC). On August 23, 1936, the first health expedition set off for Spain while, in almost parallel fashion, the British Government signed the NonIntervention Agreement according to which it pledged not to trade with either of the two sides. The Non-Intervention Committee, created to ensure compliance with the agreement, was based in London.

Also, during the first months of the conflict, different groups joined the militia in the defence of Madrid, transferring to the International Brigades early in 1937 (Baxell, 2004); other groups, from the United Kingdom in particular, were involved in supporting the rebels, (García, 2008: 221-227). Some 2,500 men and women travelled to Spain to collaborate and fight for the Republic, while in the UK itself, numerous activities were organised in order to provide humanitarian aid. For a politically and socially diverse section of the British population, the Spanish Civil War was one of the most moving and motivating experiences of the century (Alpert, 1984) in which the organisation and the aid provided represented one of the major movements in the history of $20^{\text {th }}$-century Britain (Fyrth, 1993).

In order to mobilise the population and involve different organisations, meetings and rallies were held which in many cases made use of film, so as make the meetings more exciting and interesting; in the words of Thorold Dickinson" "the films were meant to warm up the audiences before the highly skilled speakers began their appeal for funds" (Dickinson, 1984).

The importance and volume of film production related to the Civil War is detailed in the catalogue by Alfonso del Amo and María Luisa Ibáñez Ferradas (Amo and Ibañez, 1996), and in the works of Magí Crusells (Crusells, 2003) and Román Gubern (Gubern, 1986), especially in its propaganda role. In the case of the British production, film was employed to give evidence of foreign intervention - the German and Italian professional armies against the civilian population - which led to questioning of the non-intervention agreement signed by the British Government, to mobilise the necessary aid and to show the results of the assistance provided.

The scope and characteristics of British humanitarian aid have been studied by, among others, Jim Fyth (1986 and 1993) and Michael Alpert (1984) from a global perspective and by Farah Mendlesohn (2002) in the case of the work of the Quakers of the Society of Friends (S. of F.). To date, no work exists linking British humanitarian aid and the Civil War with film production, though the use of the media by humanitarian organisations has been studied in recent works, such as the project coordinated by Johannes Paulmann (2019). One aspect, relatively novel in this kind of study, is the concept of transnational solidarity studied by Karen Braskén (2015) in relation to the Workers International Relief (WIR), an organisation initially created with the aim of helping victims of the famine in Russia and neutralising the information that blamed this famine on the political situation in the USSR; once this situation had been resolved, the WIR declared that: "Its work is that of practical International Solidarity. Its aim is to create a permanent Workers' Relief Organisation distinct and apart from the agencies of bourgeois philanthropy ${ }^{2 "}$. One of the WIR's tools was precisely the use of film because, as Münzemberg wrote, "it produced a much stronger sensation and had a much greater effect on people" as result of which it even proposed new genre, proletarian cinema (Braskén, 2015: 163). As we shall see throughout the text, the idea of establishing a type of cinema made by and for the working class took shape in the UK in the creation of a significant number of groups, some of which also became involved in the production and screening of films to raise funds for humanitarian aid in Spain, with the study undertaken by Bert Hogenkamp (1986) particularly relevant in this respect.

Humanitarian aid was one of the few mechanisms by means of which is was possible to offer help without violating the non-intervention agreement. Bodies like the General Relief Fund for Distressed Women and Children in Spain or S. of F. sent help to both the rebels and the Republican government (Alpert, 1984: 33). Other organisations, however, were clearly partisan: the Spanish Relief Fund and the Bishop's Committee for the Relief of Spanish Distress sent aid to the rebel zone while the Women's Committee Against War and Fascism sent it to Republican Spain, and even organisations and movements like the International Solidarity Fund - whose funds came from campaigns organised by the TUC and Labour Party - specifically to help workers affiliated to the Unión General de Trabajadores (UGT, General Union of Workers) and the Partido Socialista Obrero Español (PSOE, Spanish Socialist Worker's Party) (Buchanan, 1991: 63). In any case, aid was initially provided in republican territory where international organisations collaborated in helping the displaced civilian population, setting up canteens and children's camps, and distributing essential foodstuff and utensils (Petrus, 2015; Kershner, 2011), as well as setting up hospitals.

Most of the organisations established in the United Kingdom worked under the umbrella of the National Joint Committee for Spanish Relief (NJCSR), an organization created to coordinate aid destined for Spain and to raise funds. As a result of this mobilisation they sent medical aid -ambulances, material, doctors, nurses and stretcher-bearers, food and warm clothing, took in thousands of children in both British, Spanish and French territory, and helped Spanish refugees in French concentration camps to escape to various American countries. The NJCSR set up meetings and associations with Catholic, Communist, Socialist, pacifist and Conservative sympa- 
thies. To avoid possible friction between members, the Committee declared ${ }^{3}$ :

From the beginning, it was agreed that though the organizations as autonomous bodies remained free to give help according to their individual views or preferences, the work of the Joint Committee itself should be purely humanitarian and non-sectarian in character.

In general, with the exception of the aforementioned bodies, inspiration was more humanist than political (Jackson, 2011: 96-101; Bruley, 1980: 282) - especially in the case of medical aid ${ }^{4}$, which has been studied in depth by Linda Palfreeman (2012 and 2014)- although the line between the political and the humanitarian is very blurred. As is noted by Sebastiaan Faber (Faber, 2010: 38 ), most 20th-century displacements of the population as a result of military conflict are rooted in political questions that involve the expulsion or elimination of the other, so that assisting the displaced, those collectives singled out and persecuted on account of their identity, is in itself a political act. Specifically, the Spanish Civil War represented for many the struggle against the advance of Fascism, a transnational movement that united diverse groups behind a common cause and between which propaganda helped to build bridges (García, 2016: 572). In fact, in relation to film-making, humanitarian aid and groups close to the Popular Front, similar synergies arose and were studied by Sebastiaan Faber (2010 and 2016) and Sonia García López (2013) vis-à-vis mobilization in the USA, and Inmaculada Sánchez Alarcón (2009) in reference to France. The groups formed in different countries interchanged films, for example, some of those produced in the USA were screened in Great Britain in order to raise funds and, at the end of the war, British and French organisations collaborated in the production of films about the refugees on French soil.

The motivation behind the decision of British people to involve themselves in the defence of, above all, the Spanish Republic, has been addressed in relation to the different political movements of the age -fascism, communism, nationalism and the workers' movement(Mates, 2007; Buchanam, 1991; Baxell, 2012), with the groups involved in offering aid, especially in the case of Catholic groups (Edwards, 2013) or with the participation of women, where the work of Ángela Jackson (Jackson, 2011) stands out in particular. The state of opinion with regard to the war in the UK and its relationship with propaganda has been another of the elements of most interest to academics, being of particular relevance the works of Hugo García (2008) and Anthony Aldgate (1973), the latter demonstrating that the censorship of the news served in practice to limit the content of the information about the conflict, in such a manner that the latter would be consistent with the arguments employed by the British Government in order to maintain the Non-Intervention Agreement. Notable too in this respect is the work by Paul Preston (2008) on the international war correspondents operating in Spain, who via the reports and articles they sent to their newspapers contributed to shaping public opinion in their respective countries.

This work analyses British film production during the Spanish Civil War in relation to the conflict and, specifically, that produced by humanitarian organisations or in which these participated. The initial premise is that the production and screening of films was related to progressive left-wing groups with links to working class film organisations; however, humanitarian organisations also made use of film to document their work and elicit further support and, in this use, they took advantage of the distribution structures set up by the progressive organisations where, in addition, they had a significant pool of support for their cause. In order to study the production, there is in-depth analysis of the context in which these films were made, in other words, of the development of the humanitarian aid in Spain undertaken by the different organisations since, as producers - in the sense of taking the initiative of making the films - without knowing how they functioned it is difficult to understand the message they seek to transmit. Moreover, there is contextualisation of the state of the cinema at the time in terms of the situation of film-making and the prevailing artistic trends, but also with regard to the intended use of these films, since the majority were conceived to be screened at meetings where both information and message could be completed. Meanwhile, the historical conditions in which they were produced, the goals pursued and the audiences to whom they were shown determined the theme chosen and conditioned the point of view from which the latter was addressed (Burke, 2001:23-76), which is why it is essential to study all these factors prior to effecting an in-depth analysis.

Whenever possible, primary sources were employed, specifically those to be found in the archives of the British Film Institute (BFI), Marx Memorial Library (MML), Labour History Archive \& Study Centre (LHASC), Modern Records Centre (MRC) and Archivo General de la Administración (AGA) and which were compared with the literature published to date. The author also saw most of the films that are conserved, almost in their entirety, in the Filmoteca Española (FE) and the British Film Institute (BFI), whenever their condition made this possible.

\section{CINEMA AND HUMANITARIAN AID: BACKGROUND}

The organisation of international humanitarian aid was not something new in inter-war Europe. The consequences of the Great War had led to massive population displacement and situations of hunger and misery. The total war waged during the conflict resulted in its extension to all social, political and economic spheres, the use of new, more destructive strategies and the disappearance of the distinction between combatants and non-combatants (Sánchez Dura, 2007:58-63), which in turn transformed aid and help for civilian society into a political weapon. As a consequence of this total war, private, charitable organisations emerged with a desire to help civil- 
ians, like, for example, Committee for Belgian Refugees, in 1914, or Fight the Famine Council, in 1918, both in the United Kingdom. In the sphere of international relations, the war led to the creation of the League of Nations, in 1919, with its mission to maintain peace, and of the High Commissioner for Refugees, led by Fridtjof Nansen, in 1922.

When in the early 1920 s the Soviet government launched an international request for aid owing to the severe famine that was devastating the country, Save the children, L'Union internationale de secours aux enfants, the Swiss Red Cross, Secours ouvrier international, the American Relief Administration and the Worker's International Relief mobilised and/or were expressly created to tackle the situation, and used the cinema in their fundraising campaigns. For instance, some of these productions were Camp of Gouda (Our Belgian Refugees in Holland) and Views of Uden (Our Belgian Refugees in Holland), produced in 1916, La guerre gréco-turque: action de secours en faveur des réfugiés grecs, in 1923, or those made to raise funds to relieve the famine in Russia The Russian Famine (Film Nansen) and Famine, the Russian famine of 1921.

Meanwhile, from the 1920s onwards, both in Europe and in America, a proletarian film movement was taking shape that assigned different uses to the cinematographic medium, not only as a source of information and of propaganda - as was the case during the First World War-, but also as a tool to be used in workers' conferences and to attract new members to organised political activities (Kepley, 1983: 7). The origin of this movement is usually located in the Workers' International Relief $^{5}$ (Internationale Arbeiterhilfe, WIR), a body created in Berlin in the 1920s with the two-fold mission of alleviating the consequences of the famine that was affecting Russia and counter-acting the negative information that attributed this situation to the political situation in the country. Once the crisis was over, the organisation began to help, on an international scale, striking workers, and set up an information network headed by the German communist, anti-militarist and propagandist Willy Münzemberg, Comintern propaganda chief in Western Europe (García, 2007: 682) and linked to the Negrín government's propaganda. From a film-making perspective, the WIR was responsible for the production of emblematic Soviet films of the period, such as those of Eisenstein, Pudovkin or Vertov (Campbell, 2004), films that were screened on the British circuit. With regard to humanitarian aid, the WIR is closely associated with the concept of international solidarity, for which film production was not only important as a means of disseminating the organisation's ideas, but also helped to create an imaginary in which the Other became a recipient of aid (Braskén, 2015: 23-28).

The WIR ceased its operations in 1935 and the baton was passed to the Popular Front and to workers' and progressive cinematographic organisations, like the Worker's Film and Photo League, with headquarters in both America and the UK (Kepley, 1983: 19-20).

\section{BRITISH HUMANITARIAN AID}

In order to learn more about the situation in Spain, and more specifically, in Madrid, a group of British MPs travelled to the country between November 19 and 20, 1936. They arrived in Barcelona on the 22nd, from where they journeyed to Valencia - the city to which the Republican government had moved - and finally, they proceeded to Madrid. The group was formed by members of the three political parties in the government: Unionist MP Crawford Greene, Wing-Commander A. E. James and Captain J. R. J. Macnamara; Labour MP F. Seymor Cocks and D.R. Grenfell; and Liberal Wilfred Roberts. The objective, they announced, was of a humanitarian nature. In the report ${ }^{6}$ drafted upon their return they indicated that:

Hospitals were crowded, and ambulances needed for transportation of cases from city in order to relieve the pressure. The Government was fully occupied in the work of defending the city. There is a great need for organized humanitarian effort. We concluded that this can only be done from outside.

Among the most urgent measures to be adopted they noted the need to evacuate the civilian population, to supply food, fuel and vehicles for transport and to send gas masks owing to the attacks that had occurred employing this kind of weapon.

On their return to England, at the suggestion of liberal Wilfred Roberts (Bruley, 1980: 281), the decision was taken to establish a humanitarian aid committee in order to prevent the overlapping of the different resources that had been established, facilitate the collection and distribution of aid, and to send other material to Spain. And thus, the National Joint Committee for Spanish Relief (NJCSR) was set up, in 1937.

Presidency of the committee corresponded to the Duchess of Atholl - Katherine Stewart-Murray, Conservative MP-, vice presidency to the Countess of Listowell -Eleanor F. Rathbone, Independent MP — and the secretary was Isabel Brown - Labour Party, Communist member - while her husband, Ernest Brown - also a member of the Communist Party - was the National Organiser (Bruley, 1980: 281). Wilfred Roberts became treasurer while the post of honorary secretary was occupied by some of the MPs who had formed part of the expedition to Madrid: D.R. Grenfell and Capt. J.R.J. Macnamara. The NJCSR embraced a significant number of societies that decided to join forces to undertake humanitarian intervention in Spain: the Social Service Council of the $\mathrm{S}$. of F., the Save the Children Fund (SCF), the Spanish Medical Aid Committee, the Scottish Ambulance Unit, the Spanish Women's Committee for Help to Spain, the Women's Committee Against War and Fascism and the Spanish Youth Foodship Committee, later to be joined by the University Ambulance Unit and new organizations like Foster Parents Plan for Children in Spain (FPP). By 1938, around 150 different organisms were working under the auspices of the committee (Alpert, 1984:33). 
As well as the MPs, many of the Committee members also visited Spain to see the situation first-hand: Isabel Brown - in August 1936, as a member of the British Anti-fascist Committee-, the Duchess of Atholl, Eleanor Rathbone and Labour MP Ellen Wilkinson. In the spring of 1937, they formed a delegation of women to carry out one of these visits, and were joined by Dame Rachel Crowdy, representing the League of Nations (Jackson, 2002: 142-143). Upon their return, many of them organised meetings accompanied by film screenings in which they related their experiences as eye witnesses of the situation.

The three most urgent questions with regard to which the decision was taken to act were those indicated by the MPs upon their return from Spain: taking care of refugees, especially children; moving the civilian population from battle areas; and medical aid. In order to be operational, they divided these issues among different members according to previous areas of activity. Regarding care of refugees, they relied upon the experience of SCF and the S. of F., specialised in supplying milk and other needs to children and which, in the case of the latter, had representatives working in Spain via the Spanish Social Service and Relief Committees. The Youth Foodship Committee and the Spanish Women's Committee raised funds to send food and winter clothing for the refugees. Concerning evacuation, various expeditions of buses, trucks, cars and drivers were sent under the direction of G. T. Garratt, taking advantage of these expeditions to send food and supplies. Medical aid was concentrated around the SMAC and the Scottish Ambulance Unit who devoted their efforts to the provision of ambulances, hospital and the dispatch of medical supplies and staff.

As the war progressed, following the bombing of Guernica, the Committee involved itself in the evacuation of Basque children, transferring some 4,000 to England, collaborated with the running of children's camps in the north of Catalonia and the south of France and, once the war was over, maintained and extended its support for Spanish refugees both in England and in France, helping the latter to abandon the country.

Most of these organisations depended on their own resources so it was vitally important to mobilise public opinion and sympathisers who collaborated with the maintenance of the different aid measures. Diverse strategies were employed: the NJCSR organised aid collection and distribution, shipments were centralised, and costs reduced via wholesale food purchases (Alpert, 1984: 33). In addition, the NJCSR contacted different civil organisations already in existence, from reading clubs to religious communities and even scout groups, and local and regional committees were created that collaborated very actively in the search for sympathisers and resources.

Already these are springing up in various places, many of them organized on a comprehensive basis to include the churches, peace societies, and a great variety of other local organizations. Groups have been formed to knit warm woollen garments, house to house collections of food have been undertaken, street collections, concerts, exhibitions, are all ways in which effective help can be given ${ }^{7}$.

Other formulae used to raise awareness and mobilise public opinion included publications in newspapers, pamphlets and books, door-to-door campaigns, exhibitions, concerts, rallies and meetings in which the cinema played an important role.

\section{The film scene in the UK}

In the United Kingdom, various left-wing groups decided to combat the vision that the film industry transmitted to society, creating film societies like the London Workers' Film Society, in which cinema was regarded as a tool with which to bring about a change in society, for which, as well as producing some films - generally compilations - they screened Soviet films of interest, they reasoned, on account of having been made by and for a non-capitalist culture: the films that a few years earlier had been produced by the WIR. These groups benefitted from the growth in film-making resulting, in terms of both production and screening, from the development of the sub-standard and safety film format (Low, 1979) which, amongst other factors, made the equipment easier to use and meant it was no longer necessary to be in possession of a licence for screenings, which in practice made it possible to show Soviet films, banned on the commercial circuit - eluding the system of censorship applied by the British Board Film Censors (BBFC) and the rules set out in the Cinematograph Act (1909).

The British Council had imposed very strict conditions according to which no film could be shown that contained subversive material, could jeopardise public peace or offend public sensibilities; it was argued that the audience went to the cinema to be entertained and to relax. Under this standard, films such as those made in Communist Russia were not suitable for the commercial circuit. The workers' film societies functioned as a counterweight to this system, establishing a type of cinema independent from the commercial circuit, offering an alternative to the ideology and values transmitted by the latter. However, this circuit was directed at groups of sympathisers, assembled at rallies or book clubs like the Left Book Club.

The Federation of Workers' Film Societies (FOWFS) led by Ralph Bond (Burton, 2000: 47), the Workers Film and Photo League (Campbell, 2004: 23), Progressive Film Institute (PFI), Kino Films Ltd., International Sound Films or Unity Films were some of the most important examples of components of this alternative circuit (Hogenkamp, 1976).

The Company most involved in the screening of films related to the Spanish Civil War was Kino Films which distributed films in $16 \mathrm{~mm}$ format, while the Workers Film and Photo League (WFPL) was responsible for producing the films (Burton, 2000: 48) along with PFI which, in addition, distributed the films in $35 \mathrm{~mm}$. Grierson and the 
documentary movement as a whole did not get involved in the conflict (Low, 1979: 166-171) and only some members, Paul Rotha and Ralph Bond, participated indirectly.

Even under the strategy of employing an alternative distribution circuit, films related to the Spanish Civil War were censored. For example, the North American documentary Spanish Earth (Joris Ivens, 1937), on the theme of cultivating the land, was presented to the censor in October 1937, and denied a certificate until the elimination of references to the intervention of the German and Italian air forces and "shocking details" such as swastikas visible on German planes (Ryan, 1986:72). The BBFC even prevented the film from being shown at the International Peace Congress in London. Other films censored included Sunshine in shadow or Britain Expects ${ }^{8}$.

\section{FILM PRODUCTION: SHOWING ANOTHER REALITY}

The production of films related to humanitarian aid was undertaken in different spheres: newsreels, amateur film-making and by progressive humanitarian organisations. The British film industry, on the other hand, had scarcely any direct involvement in the Spanish conflict, so the films that were used were generally distributed and shown outside the commercial circuits.

The government's non-intervention policy and the news' agencies' support of this policy meant that the information citizens received was biased. Counteracting this information in order to prompt a change in British foreign policy was a constant throughout the conflict. Regarding production, according to Magí Crusells, of all foreign film production dealing with the conflict, the UK's was the largest, with a total of 32 films (Crusells, 2004: 86).

Criticism of the non-intervention agreement was based upon two issues: the impact of the war upon the civilian population - especially the consequences of air raids on cities, which particularly affected women and children, and its need for safety and food-, and foreign military intervention - pitting the image of professional soldiers against that of the international brigades: civilian volunteers, idealists - . The content of these films was clearly political in inspiration and manifested specific support for the republican government. The latter actually supported and participated in many of the productions: showing the normality of the regime, the care of children, the advances in education and the fight against illiteracy, or the population's support of the government were some of the themes addressed. The line separating political and humanitarian organizations was sometimes blurred and complicated the work of the NJCSR, for instance, regarding the Basque children. As well as political questions, other elements were introduced and adapted to humanitarian aid requirements and the most significant developments in the conflict. The need for funds to continue developing relief work and, in particular, help for children were the main themes. The reception of children in England was initially regarded as temporary, but the evolu- tion of the war saw their stay extended and the exhaustion of many of the resources generated by the Committee. Furthermore, their arrival prompted a propaganda war with questioning of the need for the children to remain on English soil, on the grounds that their presence was for political rather than humanitarian reasons. These campaigns resulted in a reduction in resources which jeopardised the Committee's work ${ }^{9}$.

At the end of the war, needs centred on the departure of refugees to France first, and to Mexico and other host countries afterwards. These last films were made in France, by the Central Sanitaria Internacional (CSI, International Health Centre), - responsible for organising international medical aid and for the coordination of all the aid committees (Palfreeman, 2012: 55-56) - an organism with which both the SMAC and the NJCSR collaborated. These films focused on denouncing the conditions of refugees in France, showing the solution - the refugees' departure by ship destined for different host countries - and the welcome and new life that awaited the Spanish émigrés.

\section{Newsreels to show humanitarian aid}

However, generally speaking the five main news agencies - Gaumont British News, British Paramount News, Universal News, British Movietone News and Pathé Gazette - were controlled by British and American film corporations, and maintained the government's official policy of non-intervention and therefore censored anything that might contradict the latter, such as the German and Italian intervention and bombing of the civilian population (Aldgate, 1979) and systematically eliminated the most distressing footage (García, 2007: 689). Nevertheless, there were occasional contributions.

With regard to newsreels, it is unclear whether or not British-Gaumont's proposed collaboration with the SMAC took place, though both the medical unit's departure from England and the evacuation and reception of Basque children were reflected in various items. Succour for Spain: First British ambulance leaves for Spain where the Mayor of Holborn wished the British Ambulance Unit luck just before it leaves London. Basque children evacuated from Spain showing preparations for the evacuation of the children, by means of identification and medical examination - a fundamental question to facilitate acceptance of the children by British citizens and reduce the fear of transmission of infectious diseases-. Evacuated Basque children arrive in England shows the children arriving in England and at the NJCSR Basque Children's Camp, which served to send a message of thanks to the British people ${ }^{10}$, read in English by one of the refugees: "We wish to thank the English people for their kindness and we are much better here than in Bilbao"11. The NJCSR publically acknowledged British-Gaumont's collaboration in its bulletin $n^{\circ} 8^{12}$ although in the first two reels the relief work is attributed to the Red Cross. The British Red Cross did not intervene in this process and the confusion arose from the fact that the SMAC decided to use the emblem of a red cross as an international symbol of medi- 
cal assistance $^{13}$. In fact, Eleanor Rathbone, one of the promoters of the NJCSR, sent Leah Manning to Bilbao to conduct a medical examination of the children who were to be evacuated (Jeger, 1937:14) in the Habana.

PFI, one of the companies that made most films dealing with the Spanish conflict, also collaborated with news film companies. In a letter from Sidney Cole —a film director who participated along with Montagu in several films produced by PFI - to historian Jim Fyrth, the former stated that at least a part of the material shot in Spain was sent to Pathé News in exchange for payment ${ }^{14}$. In similar fashion, these newsreels included material filmed by Alan Lawson on the bombing of Barcelona, bombing of British ships in Tarragona or the Republicans preparing for the Francoist advance (Ryan, 1986: 223).

\section{The humanitarian organisations}

As far as the organisations involved in humanitarian aid in Spain were concerned, not all of these made use of cinema or participated directly in the production of films; nevertheless, interest in the use of the medium was very widespread and, as well as counter-acting official information, it was employed to raise funds and to show sympathisers the results of their collaboration and effort.

This interest ranged from the continual use of the medium by organisations like the NJCSR to a more cautious use such as in the case of organizations like Society of Friends (S.of F.). Hesitation regarding the use of film revolved not around the efficiency of the medium, but around questions such as cost or propaganda use. For instance, the Quaker Alfred Jacobs - head of the S.of F. mission in Barcelona-, aware of the need for visual evidence to arouse international awareness and report back on the work done, stated: "We have been wondering whether the time has come to take a cine film of our work here and whether it would be worth the price of the film" (Norris, 2006: 322). The SMAC, meanwhile, in meetings held with the TUC and the Labour Party, considered Gaumont British News' proposal according to which one of the members of the medical unit would carry a camera in order to film images. The offer in this case did not involve a significant cost as the company would pay for materials and transport and would even pay $2 / 6$ pennies for every foot of film used in its newsreel. The decision was postponed however because "people would say they were using it for propaganda purposes (...) they had to do establish in the minds of subscribers that they were going for a purely humanitarian purpose" 15 .

In spite of the doubts, the medium was present in the activity of the different organisations: the leader of the Scottish Medical Unit, Fernanda Jacobsen, said she carried a film camera so as to take footage that could subsequently be used to raise funds ${ }^{16}$ and the NJCSR received support from different film organizations, from those born of the cooperative movement and left-wing circles - Progressive Film Institute and Kino Films, mainly — to companies like British Acoustic Films Ltd., British Movietone News, Gaumont British News or London Film Pro- ductions, and even declared that: "many other organisations have yet approached and it is hoped to secure the help and co-operation of the entire film industry" ${ }^{17}$.

The use of cinema was permanent ${ }^{18}$ and many films were produced and shown at all kinds of events and fundraisers helping not only to raise funds, but also to generate public opinion. The extension of the use of this formula and its success was reflected in the complaint voiced by the Duke of Alba - Franco's official representative in England - to Francisco Gómez Jordana - Francoist Foreign Minister- in a letter written in December 1938:

Finally, and as further proof of the need for us to have films here to counter those of the enemy, I should inform you that the Duchess of Atholl, in all her electoral meetings, shows the film about the bombing of English ships in red ports "England Expects" (...). As parts of this film have been suppressed by the censor, this is an additional incentive for voters to attend these rallies, which are irritating public manifestations against us ${ }^{19}$.

\section{Volunteers and cinema: amateur film-making}

The arrival of the Basque children in England was quite an event and many films were shot by private individuals. One of the first reels filmed at the Southampton camp was intended to be sent to Bilbao to be shown to the children's mothers ${ }^{20}$; the film was probably shot by member of the Royal Society for the Prevention of Cruelty to Animals (RSPCA) ${ }^{21}$ and its whereabouts are unknown. Another of the amateur films of the children was Basque Refugees at Stoneham and a Holiday to Lands' End recorded by the reverend Henry Horton, which shows the faces of many of the children, teachers and carers at the camp where they were accommodated. The children were split into groups and sent to numerous camps throughout the country, so it is necessary to study local and regional archives in order to find new images.

The most significant amateur footage was filmed by John Cuthbert Wigham for S.of F. Wigham travelled to Spain at least three times to show the work performed by the Spain Committee between 1936 and 1939 (Norris, 2006: 5). Of his recordings, the films Spain 1937 and Third visit to Spain of 1939 survive. Wigham's films mix content related to humanitarian aid with images of curiosities typical of a tourist, for example: in Spain 1937 he shows the Cibeles, the capital's emblematic fountain, or takes advantage of the train journey from Valencia to Barcelona to film landscapes and other details.

With regard to humanitarian work, Spain 1937 included images related to British aid in general, such as images of the evacuation service or the Scottish Ambulance Unit. The film, 16 minutes long, shows the journeys between Valencia and Madrid taking supplies to the capital and them evacuating children to Valencia. To this end Wigham made the Valencia-Madrid-Valencia round-trip accompanying one of these trucks, with Ayuda de la Gran Bretaña a los niños de España (Help from Great Britain to the children of Spain) written on its side. From Valencia, he travelled by train to Barcelona, to show the medical assistance 
provided for the youngest children under the leadership of Dr. Pictet, Alfred Jacob and Janeth Perry. Third visit to Spain, is more focused on the work of the Quakers and showed one of the food distribution centres in Barcelona, where hundreds of people fleeing Franco's troops had gathered, and where food had begun to be rationed. The crisis situation was serious, and this film supported the appeal for help issued by Dr. Audrey Russell, NJCSR representative in the city, calling for the urgent despatch of more medical aid and food ${ }^{22}$. Wigham also reflected the situation in the camps at Rubi, Amatella and La Nogera (where John Langdon-Davies, one of the founders of the FPP, appears), the milk canteens, the clinics for children and their evacuation, and the participation of American aid: since, with the deterioration of the situation in Spain, the British and American Quakers joined forces.

\section{Political cinema and help for Spain}

Finally, important too was the work of the groups that succeeded the Workers' Film Societies and of those arising from the cooperative movement, in particular the Progressive Film Institute and Kino Films, and to a lesser degree the Workers' Film and Photo League and International Sound Films (Ryan, 1986). This group was responsible for most of the films produced and distributed on the subject of British humanitarian aid, some of them with a significant political content.

\section{BETWEEN POLITICS AND HUMANITARIAN AID}

The Progressive Film Institute, formed in 1935, was the organisation that produced most films about the Spanish Civil War. The person with closest relations to this group was Ivor Montagu - linked with the cooperative movement and member of the Communist party- connected with some NJCSR members, like Isabel Brown, and with those responsible for republican propaganda like Otto Katz - Andre Simon — and Münzemberg.

In November 1936, Montagu left his job as Associate Producer at Gaumont-British and along with Norman McLaren, from Glasgow, travelled to Spain, entering the country via the Pyrenees with the help of Otto Katz ${ }^{23}$. They had two $16 \mathrm{~mm}$ cameras and a modest budget. From Barcelona, they travelled to Albacete and then to Madrid, where they contacted General Miaja and other foreign correspondents like Soviet Roman Karmen, who suggested to Montagu that he start filming in the morgue. In Madrid, they coincided with Labour's Wilfred Roberts and Tory Archibald James and filmed, among other things, the German anti-fascists serving in the International Brigades: Hans Beimler, only hours before his death, and Ludwing Renn. The film was edited at Kodak's offices, in Harrow. The result was the 46-minute film The Defense of Madrid - shown in black and white despite the use of Kodachrome colour film-, considered to be the first foreign film shot in the Spanish war (Gubern, 1986: 60-66). The structure is divided into three parts and it showed ${ }^{24}$ the shameful bombardment of the civil population by German and Italian bombers, the great rally to repel the Moors and Foreign Legion and the glorious work of the now famous International Anti-Fascist Brigade.

In the film, there is an appearance by Eleanor Rathbone, Independent British MP and one of the NJCSR organisers. The third part, entitled The World Assist, appeals directly to audiences with the question Shall we send food to the people of Spain? The answer shown is a food ship sent by the USSR whilst there is a request for aid for the wounded. The idea, according to Montagu ${ }^{25}$, was to use this film at meetings and fundraisers to raise funds in order to send medical aid, so they decided not to transfer the material to a $35 \mathrm{~mm}$. Most of the images were shot by McLaren, although some scenes filmed by Montagu himself were also added. At the showing, there were talks given by Denis Nowell Pritt — Labour MP_, Isabel Brown, Leah Manning and Ivor Montagu himself. The money collected was used to help pay for the International Brigade's medical aid and, according to the NJCSR newsletter, thanks to this fundraising, after over fifty rallies and meetings, a truck was sent via the SMAC with over two tons of food and medical supplies ${ }^{26}$.

With the material used by Montagu for the film, Defence of Madrid, photographer Vera (Elkan) Morley travelled to Spain along with five ambulance trucks destined for the SMAC ${ }^{27}$. Once in Spain, she filmed the International Brigades in Albacete, the Canadian blood transfusion centre in Madrid and some fronts; the film was entitled International Column or International Brigade. As far as aid is concerned, the only item of interest is the reception of food, however, the objective of the film might have been related to the actions undertaken in England to help maintain and provide medical support for the Brigades, for which the International Brigade Dependants and Wounded Aid Committee raised funds. The film sought to transmit the camaraderie within the brigadists and how they operated, so scenes showed training, the cavalry divisions, the vehicle repair workshop, the band, and theatrical performances. The fundraising success of the Defence of Madrid encouraged the use of films at rallies and meetings.

The widespread use of films by different groups led Kino Films to create a special collection on the subject, with a pamphlet entitled Help Spain by showing Kino $16 m m$ films ${ }^{28}$ which claimed that:

Films can help you enormously in your work to aid the Spanish people fight Fascism. Not only because a film brings home to an audience, as no words can, exactly what is happening in Spain today. Not only because films raise magnificent collections. A film show, as experience all over the country has proved, is the best way of attracting larger crowds to your meeting. A film show interests people who would not come in the ordinary way. This for big shows in Town Halls, and for small shows at Trade Union Branch meetings.

In its newsletter $n^{\circ} 3^{29}$, Kino gave four reasons why it considered it interesting for an organization to pro- 
gramme meetings in which films were shown. Firstly, to raise money. The second reason was to maintain members' interest and involve them actively in the organisation, above and beyond the mere payment of membership fees. Thirdly, in order to recruit new members - arguing that people do not read pamphlets, have no time for books and are bored by speeches, but that films, however, may encourage new sympathisers to take an interest in the organisation's work - . And finally, on educational grounds, to illustrate specific problems and succeed in transmitting ideas that might involve an audience.

Over a year after this production, Montagu returned to Spain. Between the two trips he was responsible for the production of several compilation documentaries, made with material from the Spanish Ministry of Public Instruction (SMPI) —Madrid Today, a compilation on the impact of bombing upon the city and the populationand from the Confederacion Nacional del Trabajo (CNT, National Workers Central) -Crime against Madrid, conceived as a summary of the conflict and of the basic ideas that initially sustained propaganda: after the bombing of the city, help was activated, represented by the arrival of a ship with food from the Soviet Union. The consequence of the air raids is reflected in the wounded children in hospital and their evacuation, and in the face of the attack men converted into militia train and fight in the trenches, while the women work in the fields and supply the militiamen's needs, for example, making clothes with their sewing machines.

Montagu's second trip was undertaken, according to Ryan (1986: 231), at the request of Otto $\mathrm{Katz}^{30}$ with $£ 3000$ given by the Spanish republican government; according to Jim Fyrth, this money was actually Otto Katz's, from the profits of his film Nazi Conspiracy in Spain (Fyrth, 1986: 218). In any case, Montagu signed a contract with the Propaganda Under-secretary of the Republican Government, pledging thereby to send a film unit to "film the organisation and democratic activities of the Spanish Republic" and with the footage of which he hoped to make three of four shorts ${ }^{31}$. The departure from England was complicated by the need to request special permits to travel to Spain, permits that were denied by the Foreign Office. Montagu had to seek the support of Attlee, who in turn contacted with Eden in Scotland to obtain the necessary permits. Upon his arrival in Spain, writes Montagu in his autobiography Anti-fascist films of the thirties and forties ${ }^{32}$, Münzenberg was fighting with his associates and Katz had become "a sort of private public-relations officer for Republican Prime Minister Negrin $^{33}$ ". Katz's proposal was to make a series of films with a full professional team, in full-size $(35 \mathrm{~mm}$ standard commercial) and "in particular themes illustrative of the character of life and administration in the Republican zone", focused on three themes: education and the fight against illiteracy, the continuity of the constitutional parliamentary regime and the regular army. Montagu travelled alongside a group of volunteers belonging to the Association of Cinema Technicians, including: Thorold Dickinson, Sidney Cole, Alan Lawson, Arthur Graham,
Philip Leacock and Ray Pitt. Montagu was a member of this association and sat on its executive committee between 1933 and $1962^{34}$.

The team, in Barcelona, experienced the bombings by German and Italian planes, as their hotel was near the telecommunications building, one of the targets. The passes, safe-conducts and letters of recommendation signed by, among others, the Central Army Chief of Staff, the Ministry of Public Education and Health or the Propaganda under-secretary granted them access to the rear-guard and the front, to Portela Valladares and Azaña, to the International Brigades and the Secretary General of the British Communist Party, Harry Pollitt, on a visit to Spain. Before completion of recording of material for the three films, they decided to return to England due to the advance of Franco's troops. This second trip resulted in the production of two films, Spanish A.B.C. and Behind the Spanish lines, both directed and edited by Thorold Dickinson and Sidney Cole.

Spanish A.B.C. is 19 minutes long and is, as the film's title explains, "a film report of the work of the Spanish Ministry of Education". The film's structure is circular and may be divided into three parts. The first shows the growth in the number of new schools at the height of the war and counters the vision of destruction created by the enemy. The second part shows the result of some of the aid actions undertaken thanks to British aid, carried out by the SoF, amongst others, and reflected by the trucks with the words "English evacuation service" and "Aid from Great Britain for Spanish Children" written on their sides; to narrate the process of aid distribution there is a reconstruction using footage of different moments and places, edited as a continuous narrative, a common method in the documentaries of that era, and which was also used in earlier newsreels. Prominent in this second part are images of children, not only singing and playing, safe from the bombing, but also digging trenches and an airraid shelter or busying themselves with everyday chores such as hanging out the washing. The last part shows the politicians from the Ministry of Education and the places and groups that receive education, even on the front, thanks to the cultural militias, with the message "all Spain goes to school".

Behind the Spanish Lines, contrasts the apparent normality of the republic transferred to Barcelona - seat of Azaña's republican government and administrative centre too of the Basque and Catalan governments - with the chaos of war. On the one hand we see the city with its shops, cooperatives for food distribution, newspaper kiosks or flower stalls, set against the image of the militias, the remains of a bombed British ship and of a German plane, those killed by an air raid on a city and part of an interrogation of two German and Italian soldiers, Gino Poggi and Rudolf Rueker, captured in Barcelona and whose full interrogation would be shown as an individual film entitled Testimony on non-intervention. The aim of the film was to illustrate foreign military intervention in Spain and counter the reasoning behind the non-intervention agreement and, moreover, begin to show that the war in Spain 
had a direct impact upon British interests. The bombing of British ships became a recurrent theme and prompted the making of the film Britain Expects.

According to Montagu $^{35}$, the film was shown, reduced to a $16 \mathrm{~mm}$ non-flammable format, to a large audience at London's Queen's Hall, which required no licence for its screening and despite attempts by the Swiss authorities to block it, at Geneva during the League of Nations meeting to debate about Spain.

Also, in 1937, with material sent from Spain, the 45-minute film News from Spain was made, a production by Herbert Marshall, member of the PFI, in $16 \mathrm{~mm}$, including a commentary by Isabel Brown of the Relief Committee for the victims of Fascism, and showing the air battles between the government aircraft and the German and Italian planes, the International Brigade and the bombing of the civilian population.

The last film with a political content was Britain Expects $^{36}$. Produced by PFI along with Unity Film, it benefitted from the cooperation of the Committee of British Ship-owners trading to Spain, the Officers Merchant Navy Federation and the National Union of Seamen. The objective of the film was to involve all of society in the Spanish conflict, showing the damage done to the country's interests due to the constant bombing of English merchant ships. It referred to the UK's need to transport goods by sea, to and from its colonies, and the losses being suffered as a consequence of the attacks by Francoist forces, stating that a very high proportion of the ships sunk in the Mediterranean were British - 140 compared with 12 French ships-. Using diagrams created by Publicity Pictures Limited, it showed the degree to which Germany and Italy had penetrated Spain, in both military and economic terms, to the detriment of Britain's interests $^{37}$. Meanwhile, it was claimed that the ships destined for Spanish ports only carried food for the refugees and were checked by members of the Non-intervention Committee, thus ruling out the possibility of the bombing resulting from violation of the agreement. The film, shot in $35 \mathrm{~mm}$, had censorship problems regarding its screening in commercial cinemas and was not approved by the BBFC until the last days of 1938, following the removal of a series of comments on Chamberlain, Hitler and Mussolini $^{38}$, as a result of which it was reduced to $16 \mathrm{~mm}$ and distributed by Kino Films. It was supported by the Duchess of Atholl, who employed it in her electoral campaign meetings, and was also used by the Spain Emergency Committee to put pressure on the Prime Minister to eliminate the policy of non-intervention ${ }^{39}$.

The producer, Unity Films ${ }^{40}$, had been created by Basil Burton, Elsie Cohen and George Hoellering for the distribution - and later production too - of non-commercial films in $35 \mathrm{~mm}$ and was close to the workers' film movement (Ryan, 1986: 248). Direction of the film was attributed to Ivor Montagu ${ }^{41}$ but the initial credits show Charles Tomrley, Max Anderson as assistant, J. Parker and W. Creamer as camera operators and Derek Birch as narrator.

Most of the films produced by PFI on the conflict were distributed by Kino Films (Burton, 2005: 46-57) which made it possible to hire the films for a day, with projector, screen and other equipment, including musical accompaniment in the case of silent movies. There were discounts for two screenings on the same night. The cost ranged between 70 and 50 shillings for films with sound to 30 shillings for a silent movie. Among the films for hire, those related to Spain included PFI productions, some produced by Kino and even Spanish films like Las Hurdes, tierra sin pan (Land without bread, Buñuel, 1933) which showed the agricultural problem in Spain before the war. Other films on offer in the pamphlet Help Spain ${ }^{42}$ were: Sunlight in Shadow, Non-Intervention, News from Spain, Crime against Madrid, Madrid To-Day, Modern Orphans of the Storm, Attlee in Spain, Spain To-Day, Alquezar, Defence of Madrid and International Column.

Other organisations linked to the alternative film circuit were the aforementioned Unity Films, International Sound Films Ltd. (ISF), Film and Photo League (FPL) and the Worker's Film Society (WFS), organisms with little involvement in the Spanish Civil War.

ISF undertook some fund-raising activities via the screening of films. Created by Sime Seruya - Suffragette and member of the Labour Party - and her son Ivan, in the autumn of 1936 it declared itself "Specialist in all forms of propaganda"43. Occasionally it raised funds destined for the maintenance of Basque children, medical aid, food ships or shipments of milk. ISF functioned in parallel with Kino and PFI as a distributor of progressive films in 35 and $16 \mathrm{~mm}$; these included New Spain -a compilation film made by Luis Buñuel and the French Communist Party, also known as Madrid 1936 - and it produced Spanish Gazette using material recorded by Ivan Seruya in Spain in 1937 (Ryan, 1986: 341-342).

With regard to the Co-operative Movement and the WFS, the NJCSR tried to reach collaboration agreements with them. The search for funds led the Committee to consider increasing the use of films in its meetings, so they contacted Paul Rotha - member of the British documentary movement headed by John Grierson- and Joseph Reeves ${ }^{44}$, with connections to the Workers' Film Society, PFI and secretary of the cinema committee of the National Association of Co-operative Education Committees (NACECS) (Burton, 2005: 50). NACECS organised 116 film shows in relation to the TUC and the Labour Party "Milk for Spain Fund" campaign ${ }^{45}$ with films about the Spanish conflict. This collaboration led to the production of the film Milk for Spain Appeal, which it has not been possible to consult due to the deteriorated condition of the negative. Reeves took part in some rallies along with Isabel Brown ${ }^{46}$, but he did not however answer the call by the British Committee for Refugees in Spain — part of the NJCSR for the coordination of international aid for Spanish refugees in France - to collaborate in the production of films, claiming that before becoming involved, his organization - the Workers' Film Association - required detailed information regarding questions such as the length of the film ${ }^{47}$. It is my understanding that this collaboration did not come to fruition. 
Film and Photo League, meanwhile, did produce, in October 1937, a film entitled Spain 1936-1937 (Ryan, 1986: 534).

\section{The focus on children}

Children, as the most vulnerable victims of the conflict, received special attention in terms of care and when it came to filming the latter for fund-raising campaigns. The Quakers, S.of F., were the first to produce a film, in 1936, on the work being carried out in Spain in school camps, entitled Aid Spanish Children!. The film shows the effects of bombing upon the population and the reception of children "who have lost home and family" in the boys' camp at Crevillente, sponsored by Anglo-American \& Quakers' aid (National Federation of Pioneers). The film shows the children doing sport, washing, looking after the farm animals, eating and leaning carpentry and agriculture. The aim of the film was to show the organisation's work educating the children, so they might have a future and bringing them some happiness, reflected in low-angled shots of their smiling faces.

The bombing of Guernica, in April 1937, prompted the NJCSR, which was undertaking evacuation procedures within Spanish territory, to decide to evacuate 4,000 children to England. Initially this was thought to be a temporary measure, but the evolution of the war proved otherwise. After a medical check-up, the children were accommodated in a camp in Southampton. Almost 2,000 children remained in the committee's care, while the Salvation Army and Catholic groups took care of the rest.

There were many problems involved in supporting the children since, in addition to the cost, a campaign began for, once Bilbao fell to Franco's forces, their return to Spain. Some returned, but the majority stayed and, as a result of this campaign, economic resources decreased at an alarming rate $^{48}$. The NJCSR resorted to film, among other media, to mobilise sympathisers.

It is important to keep the children, to a certain extent, in the public eye, and to create a friendly feeling for them. If people are in actual contact with them they always get to love them. We hope our friends will go out of their way to get to know the children, and to introduce others to them ${ }^{49}$.

To illustrate the children's situation, the NJCSR produced the film Modern Orphan of the Storm. The story of the refugee Basque Children in collaboration with Realist Film Unit and Victor Saville Productions. Directed by Basil Wright in association with Ian Darlimple - with whom Saville, with roots in the film industry, had established his production company approximately one year earlier - and narrated by E. V. H. Emmett. Distributed in $35 \mathrm{~mm}$ by the NJCSR and in $16 \mathrm{~mm}$ by Kino, it is a sound film around 20 minutes long and features songs sung by the children themselves. It was offered rent-free provided its use was to raise funds for the children ${ }^{50}$, and sympathisers were even asked to request that cinemas in their area show the film and allow a collection to be made. Filming at the camp lasted three days, during which all kinds of activities were performed, from traditional dances to boxing matches. According to the NJCSR both Victor Saville Productions Ltd. and the Realist Film Unit had provided their services and equipment free of charge ${ }^{51}$.

The film, as in previous cases, reuses earlier material and introduces a reconstruction. The beginning seeks to place the spectator in the context that led to the children's flight, the bombing of Guernica, showing images of the bombing that previously had been used in the film $M a$ drid Today (Low, 1979: 187-188). The reutilisation of material was a common practice during the Civil War, creating what were known as assemblage or compilation documentaries. Another regular technique, also employed in this film, is that of dramatization, whereby characters re-enacted an event that supposedly had already taken place. In the case of Modern Orphans of the Storm, the dramatization shows a meeting with the participation of the Duchess of Atholl, president of the NJCSR, in which the decision is taken to evacuate the children to England. Finally, the film shows the situation of the children in the camp, their daily routines and distribution among the different camps

The evacuation of the children was exploited by both sides as a propaganda tool. By the rebels, to indicate that the situation was now normal, and they could return without any problem, and by the republicans, as evidence that the danger continued, and the children could not be safely returned to their parents.

\begin{abstract}
The propaganda campaign against the children has so far succeeded that large sections of the public think that they have all gone home, or that they should go home and have homes to go to, and in some quarters, support for them is temporarily drying up. This must be overcome if our duty to the children is to be carried out ${ }^{52}$.
\end{abstract}

Almost a year after Modern Orphans of the Storm, around March 1938, the NJCSR produced Save the Spanish Children in collaboration with Kino Films, with the clear goal of raising funds for the children. To the problems generated by the propaganda campaigns was added the fact that their stay in the UK was proving to be longer than had initially been anticipated and the Committee maintained, moreover, five school camps, one of them in Puigcerdá. There was an attempt to resolve the problem of the children's maintenance by means of sponsorship, with the creation of the organisation FPP by journalist John Langdon-Davies and the English volunteer Eric Muggeridge and where Nick Carter played an important role in the evacuation of children. The organisation, linked to the NJCSR, promoted the sponsorship of children, mainly from England, by contributing 10 shillings a week and sending gifts in the form of clothing and food. As regards the children still in Great Britain, the film recalls their arrival with images from the first film and there is an appeal for collaboration, without which the children will have to return to the horror of the bombing: 
The injured need medical supplies. Help Spain's homeless children. We need money to feed them, money to keep them in decent homes and colonies where they can be happy and forget the horrors they have been through.

The presence of children as an incentive for humanitarian action was a method constantly employed by all the aid agencies and was a strategy that had already been successfully used in Save the Children's campaigns to raise funds to combat the famine in Russia.

The films in which there was a direct appeal for help for the children -along with Blood bank service in Spain, which shows the process of blood donation and could serve as teaching material for new nurses - avoided the inclusion of images or slogans that had political connotations and showed the children happy and healthy thanks to the aid they had received.

Kino Films participated in other productions with the NJCSR, and the Committee even coordinated its activities with this organization (Ryan, 1986: 201). These productions included: Schools in Catalonia, Mr Attlee in Spain on this politician's visit to Spain and his encounter with the International Brigades and Blood bank service in Spain which shows the process of a blood donation and which could act as training material for newly qualified nurses.

Between late 1937 and early 1938, cameraman James Calvert was sent to film the treatment of wounded brigade members and the Committee's work in refugee centres (Hogenkamp, 1986: 167). The result was Help Spain ${ }^{53}$

This is the only film in existence which deals entirely with relief work. It runs for some 35 minutes and can be used as a special attraction at all kinds of functions, especially in country and small town areas.

To promote it 5.000 copies of the information leaflet were printed and Lord Listowel even made a trailer despite which "the response to date had not been good, probably due to the present crisis" 54 . The whereabouts of the film are unknown.

The situation of the children in the camps was also addressed, in 1938, in Sunlight in Shadow, Film Popular production in collaboration with the PFI and the Ministry of Public Education. Directed and filmed by Jean Lordier - who also directed for the International Bureau of Children the French film SOS Espagne (Crusells, 2001: 442). Sunlight in Shadow shows the children of Madrid in the refugee camps, and, once again, after the images of bombing and flight from the city, a day in the children's life in the camp, from daybreak until bedtime.

\section{The end of the war: Leaving France}

The last films on the Spanish Civil War, which were employed in fund-raising in the UK, were made in France with the help of the CSI and reached the NJCSR via the SMAC members, who collaborated with the Central. The focus was on helping refugees during their stay in refugee camps in France and facilitating their departure to differ- ent host countries. One of the most urgent objectives was to remove from the camps those who were blacklisted, as their lives could be in danger.

The first film to be made was shot in the refugee camps to show the poor conditions endured by Spaniards gathered there. The CSI showed the SMAC some stills from the film in order to sell the rights to the latter ${ }^{55}$ and contribute towards its financing. According to SMAC minutes, the NJCSR wanted to ensure that the film would reach England, so, Felice Clark - Asst. Sec. NJCSRmediated to the Committee assume the costs of the film, which it would rent to the SMAC for one pound a time until the full cost of the film had been paid, after which it would be lent free of charge ${ }^{56}$. The film proved to be more expensive than initially anticipated and the asking price was almost doubled; finally, the rights for England were set at $£ 80$. A $35 \mathrm{~mm}$ copy might cost around 3000 Francs (about £17) and 16mm 1500 Francs (approximately $£ 8.10)$.

For the fund-raising campaign the British Committee for Refugees from Spain aimed to use three films ${ }^{57}$ : the one about French refugees, another about the voyage in the "Sinaia" and a third about the situation of Spaniards in México. The plan was to screen the three together to give an idea of the conditions faced by Spanish refugees and show the possible solution. For the departure of the first group a ship was rented, the Sinaia, with a capacity for 1,800 people, at a cost of eleven pounds per head. For a second ship, the NJCSR needed to raise 20,000 Pounds. To make these films Joe Reeves, of the Workers Film Association was contacted, but he did not respond to the call $^{58}$.

On July 7, 1939, the NJCSR staged a double premier at St. Pancras Town Hall. The films were Passport to Life, a recording of the sailing of the first Spanish refugee ship from the French Mediterranean port of Sete where, according to the advertising leaflets, one could see how the Spanish republican refugees were reunited with their wives and children after months of deprivation and exile in concentration camps, and A people is waiting, directed by Jean-Paul Le Chanois, for which a French cameraman had supposedly smuggled his camera into the concentration camps in order to show the suffering and misery of hundreds of inmates: "This film tells the whole story-retreat into France; life in the camps; homes and colonies for women and children, and the relief work being done".

\section{CONCLUSIONS}

The humanitarian films mobilised sympathisers and showed the work of these organisations, whilst helping to generate symbols and shape public opinion. It is very difficult to make a precise calculation of the amount of money raised via their screening, especially bearing in mind that two different kinds of films tended to be shown together: those with political content and those that were strictly humanitarian. The former had been made in exchange for payment, and the distributors charged a fee for their screening. In the second case, the reels were provid- 
ed free of charge, provided they were used to raise funds. The difficulty arose from the fact that both types of film were distributed via practically identical channels and were even made by similar organisations, the workers' and progressive film organisations, heirs to the WIR's notions of solidarity and communication.

The use of civilians as military targets and the international non-intervention agreement led to a blurring of the lines that divided the humanitarian and the political. Providing humanitarian aid implicitly involved adopting a political stance. The denunciation of foreign intervention, in the hope of breaking the non-intervention agreement, increased along with the development of multiple international actions in aid of the civilian population and, certainly, both the denunciation and the appeal for help favoured the interests of the Republic. This mixture of the humanitarian and the political led the propaganda surrounding humanitarian to be interpreted as a strategy of legitimation of the republican government that had created the slogan that helping the Republic was a humanitarian imperative (Faber, 2016: 23). To what degree this was a propaganda strategy or to what degree the republican government benefitted is very difficult to ascertain, but in any case, was not the objective of the NJCSR, presided over by a Conservative politician, the Duchess of Atholl.

Meanwhile, in order to dissociate aid from partisan interests, strictly humanitarian propaganda focused on the image of the children (Holmes, 2019: 82) and, to a lesser extent, on medical aid. The image of children as symbol of the innocent victims of war had been employed by Save the Children and the S. of F., in relation to the humanitarian aid sent to the Soviet Union in order to relieve the famine that followed the First World War. This aid campaign was subjected to some questioning and political prejudice that were deployed during the Spanish Civil war, vis-à-vis the possibility of helping the communists.

In spite of the blurred boundary between politics and the aid provided, idealism and humanism prevailed and the desire to help remained strong, even decades after the conflict.

\section{ACKNOWLEDGMENTS}

This article forms part of the project "European $\mathrm{Hu}$ manitarian Aid in France during the Second World War". Ref.: HAR2014-58043-P, Ministerio de Economía y Competitividad, Gobierno de España.

\section{NOTES}

1 Thorold Dickinson formó parte del equipo cinematográfico que se desplazó a España por iniciativa de Ivor Montagu.

2 The Workers' International Relief, what is it?, Workers' International Relief. British Joint Labour Aid Committee, 1925. Archives of the Trades Union Congress (ATUC), Modern Records Centre (MRC), University of Warwick, 292/771.21/6/38

3 National Joint Committee for Spanish Relief (booklet). ATUC, MRC, 292/946/18b/26(iii).
4 Report of discussion between officials of the Trades Union Congress and the Labour Party, and representatives of the Socialist Medical Association... on the subject of medical and ambulance units being sent to Spain (held on 11 August 1936), 12 Aug 1936, pp.: 3-4. ATUC, MRC, 292/946/18b/74.

5 The Workers' International Relief - what is it?, 1925. ATUC, MRC, UW, 292/771.21/6/38.

6 Visit of an all-party Group of Members of Parliament to Spain: report. ATUC, MRC, 292/946/18b/74.

7 National Joint Committee for Spanish Relief (booklet). ATUC, MRC, 292/946/18b/26(vi).

8 Letter dated May 20, 1938, sent to Mr. Brooke Wilkinson, president of the British Board Film Censor (BBFC) that affects several PFI films such as Non-intervention, Health of Spain, Spanish $A B C$ and Behind the Spanish Line. Marx Memorial Library (MML), Box B-6.

9 Plan for Winter Campaign, National Joint Committee for Spanish Relief, September 10, 1938, ATUC, MRC, 292/946/30/72.

10 Report of second meeting... ATUC, MRC 292/946/41/2, pp- 8-9.

11 Evacuated Basque children arrive in England, Gaumont British Newsreel, 27th May 1937.

12 Bulletin $\mathrm{n}^{\circ} 8$ NJCSR, July 1937.

13 Report of second meeting... ATUC, MRC 292/946/41/2, pp- 8-9.

14 Sidney Cole to Jim Fyrth, Letter of April 1986. MML, Box B6: $\mathrm{K} / 9$.

15 Report of second meeting between the Spanish Medical Aid Committee and officials of the Trades Union Congress and Labour Party, to discuss the proposal to send a Medical Unit to Spain, 20 Aug 1936, pp. 10-11. MRC, 292/946/41/2.

16 Summary of telephone conversation with Miss Jacobson of the Scottish Ambulance Unit in Spain, 15 October 1938, ATUC, MRC, 946/42/42.

17 National Joint Committee for Spanish Relief, Bulletin $\mathrm{n}^{\circ} 8$, ATUC, MRC, 292/946/39/1.

18 It is worth noting that the humanitarian aid organizations also made use of productions by organisms close to the Spanish government like Laya Films and Film Popular and screened the most important productions of similar American groups close to the Film and Photo League group.

19 Duke of Alba to Fco. Gomez Jordana, Letter of December 13, 1938, Archivo General de la Administración (AGA), Ministerio de Asuntos Exteriores (MAE), Madrid, 82/3104.

20 Bull, John: Heart of humanity camp (press cutting), June 5, 1937, ATUC, MRC, 292/946/39/106.

21 Bulletin n ${ }^{\circ}$ 7, NJCSR, 10 June 1937, p. 3.

22 Daily worker, 18 January 1939, p. 1.

23 MONTAGU, IVOR, Anti-fascist films of the thirties and forties, LHASC, CP/IND/MONT/02/05.

24 Circular, Great Film - The Defence of Madrid, December 1936, ATUC, MRC, 292/946/15b/29.

25 MONTAGU, IVOR, Anti-fascist films of the thirties and forties. LHASC, CP/IND/MONT/02/05.

26 Bulletin n. 4, National Joint Committee for Spanish Relief. March 19, 1937. 292/946/16a/36

27 Fyrth, Jim: Transcript of Vera (Elkan) Morley to Jim Hirth at her home in St. John's Wood, 13 April 1987. MML, Box D2, N1.

28 LHASC, CP/ORG/MISC/04/04.

29 Kino Bulletin $n^{\circ} 3$. LHASC, CP/ORG/MISC/04/04

30 Otto Katz was assistant to Willi Münzenberg, German propagandist and Communist connected with the Comintern. Katz was in charge of the Agence Espagne in París, created by Münzenberg and Álvarez del Vayo, Spanish minister, to supply news to the French press. (Ryan, 1986: 231). He collaborated with Isabel Brown in preparing the visit of the first British delegation of British MPs to Spain (García 2006).

31 Montagu to Cinema Department, Subsecretaría de Propaganda. Letter of January 15, 1938. British Film Institute (BFI) Ivor Montagu Collection, Spain 1938, Correspondence, Hotel Bills, speeches, clippings, etc., Folder $1 / 2$.

32 MONTAGU, Anti-fascist ... LHASC, CP/IND/MONT/02/05. 
33 Idem, p. 5.

34 MONTAGU, Ivor: Curriculum vitae, LHASC, CP/IND/ MONT/01/01.

35 MONTAGU, Anti-fascist ... LHASC, CP/IND/MONT/02/05.

36 The working title was England Expects, but the film was distributed by Kino with the title Britain Expects, filmed in $35 \mathrm{~mm}$ and transferred to $16 \mathrm{~mm}$; directed by Ivor Montagu and edited by Bill Megarry. Third Draft Script England Expects. MML, B6, K/18.

37 Prime Minister's delegation, organization International Peace Campaign. Spain Emergency Committee, p. 7. ATUC, MRC, 292/946/17b/35

38 The evening news, December 22, 1938

39 Prime Minister's delegation, organization International Peace Campaign. Spain Emergency Committee. ATUC, MRC, 292/946/17b/35.

40 Unity Films was the distributor of the North American and prorepublican film The Spanish Earth, by Joris Ivens, of which eight copies were distributed to commercial cinemas; distribution in 16mm was by Kino (Ryan, 1986: 248).

41 Third Draft Script England Expects. MML, B6, K/18.

42 Price list of $16 \mathrm{~mm}$ substandard sound (SMPE) and silent films. Kino Films (1935) Limited. Kino's main office was in London, but it had local agents in Belfast, Birmingham, Blackpool, Bradford, Bristol, Cardiff, Doncaster, Co. Durham, Leicester, Nottingham and Glasgow. LHASC, CP/ORG/MISC/04/04.

43 Daily Worker, 21 May 1938, p.6.

44 Minutes of the Spanish Medical Aid Committee, November 30, 1938. ATUC, MRC, 292/946/43/40.

45 Minutes of the Spain Campaign Committee, February 8, 1938, ATUC, MRC, 292C/946/3/21, p.2.

46 Daily worker, April 17, 1937, p. 6

47 Manning, Leah, Report of Honorary secretary on the Sinaia (refugee ship to Mexico) and the Glaser case, May 8, 1939, ATUC, MRC, /946/43/20. Fec

48 Circular by Wilfrid Roberts, NJCSR. 9 December 1937, ATUC, MRC, 292/946/37/12.

49 Bulletin n ${ }^{\circ} 10$ NJCSR, 10 December 1937.

50 Idem, p.2

51 Bulletin n 8 NJCSR, July 1937.

52 Letter signed by G. T. Garratt, Honorary Administrator of the NJCSR, Basque Children Committe, ATUC, MRC, 292/946/38/170.

53 Plan for Winter Campaign, National Joint Committee for Spanish Relief, September 10, 1938, ATUC, MRC, 292/946/30/72.

54 Minutes of a meeting, NJCSR, 27 September 1938, p. 4, ATUC, MRC, 292/946/39/20.

55 Minutes Spanish Medical Aid Committee, April 26, 1939, ATUC, MRC, 292/946/43/22(ii)

56 Minutes Spanish Medical Aid Committee, 24 May 1939, ATUC, MRC, 292/946/43/14.

57 Manning, Leah, Report of Honorary secretary on the Sinaia, 8 May 1939, ATUC, MRC, 292/946/43/20.

58 Manning, Leah, Report of Honorary... May 8, 1939, ATUC, MRC, 292/946/43/20.

\section{REFERENCES}

Aldgate, Anthony (1979) Cinema \& History. British Newsreels and the Spanish Civil War. Scolar Press, London.

Alpert, M. (1984) "La repuesta inglesa humanitaria y propagandística a la Guerra Civil Española", Revista de estudios internacionales, enero-marzo 5(1): 27-38.

Baxell, Richard (2012) Unlike warriors: the British in the Spanish Civil War and the struggle against fascism. Aurum, London.

Braskén, K. (2015) The International Workers' Relief, Communism and Transnational Solidarity. Palgrave Macmillan, Basingstoke.

Bruley, S. (1980) Socialism and Feminism in the Communist Party of Great Britain, $1920-1939$. Thesis submitted for the degree of $\mathrm{PhD}$, London School of Economics and Political Science, University of London.
Buchanan, Tom (1991) The Spanish Civil War and the British labour movement. University Press, Cambridge - New York.

Burton, Alan George (2000), The British Consumer Co-operative Movement and Film, 1896-1970. Thesis submitted for the degree of $\mathrm{PhD}$. Montfort University.

Campbell, Russell (2004) "Film and Photo League: Radical Cinema in the 1930s". Jump Cut, 14: 23-25.

Crusells, Magí (2001) Las Brigadas Internacionales en la pantalla. Universidad de Castilla-La Mancha, Ciudad Real.

Crusells, Magí (2003) La Guerra Civil española: Cine y propaganda. Ariel Cine, Barcelona.

Crusells, Magí (2004) El papel de las Brigadas Internacionales en el cine documental extranjero. Ayer 56 (4): 143-163.

Del Amo García, Alfonso and Ibañez Ferradas, María Luisa (1996) Catálogo general del cine de la guerra civil. Cátedra - Filmoteca Española, Madrid.

Dickinson, Thorold (1984) "Experiences in the Spanish Civil War, 1938”. Historical Journal of Film, Radio and Television, 4(2):189-193. doi: 10.1080/01439688400260181

Edwards, Ben (2013) With Good on our side: British Christian responses to the Spanish Civil War. Cambridge Scholars Publishing, Newcastle upon Tyne, UK.

Faber, Sebastiaan (2010) "«L'atroç crim» d'ésser antifeixista. L'ajuda des dels Estats Units d'Amèrica als republicans espanyols". In Martínez Vidal, Àlvar (coord.) Exili, medicina i filantropía. L'Hospital Varsòvia de Tolosa de Llenguadoc (19441950). Editorial Afers, Barcelona: 37-49.

Faber, Sebastiaan (2016) "Image Politics: U.S Aid to the Spanish Republic and its Refugees". Forma: revista d'estudis comparatius: art, literatura, pensament, 14: 21-34.

Fyrth, J. (1986), The Signal was Spain. The Spanish Aid Movement in Britain, 1936-1939. Lawrence and Wishart, London.

Fyrth, J. (1993) "The Aid Spain Movement in Britain, 1936-39", History Workshop, 35: 153-164.

García Fernández, Hugo (2006) "El turismo político durante la Guerra Civil: viajeros británicos y técnicas de hospitalidad en la España republicana 1936-1939”, Ayer 64 (4): 287-308.

García Fernández, Hugo (2007) "Seis y media docena: propaganda de atrocidades y opinión británica durante la Guerra Civil Española”. Hispania. Revista Española de Historia, vol. LXVII (236): 671-692.

García Fernández, Hugo (2008) Mentiras necesarias. La batalla por la opinión británica durante la Guerra Civil, Biblioteca Nueva, Madrid.

García Fernández, Hugo (2016). Transnational History: A New Paradigm for Anti-Fascist Studies? Contemporary European History, 25(4), 563-572. doi: 10.1017/S0960777316000382

García López, Sonia (2013) Spain is us: La Guerra civil española en el cine Popular Front, 1936-1939. Publicacions de la Universitat de València, Valencia.

Gubern, Román (1986) La guerra de España en la pantalla. De la propaganda a la Historia. Filmoteca Española, Madrid.

Hogenkamp, Bert (1976) "Film and the Workers' Movement in Britain, 1929-39", Sight and Sound; London, 45 (2).

Hogenkamp, Bert (1986) Deadly Parallels. Film and the left in Britain, 1929-39. Lawrence and Wishart, London.

Holmes, Rose (2019) "Make the situation real to us without stressing the horrors: children, photography and Humanitarianism in the Spanish Civil War". In Paulmann, Johannes Humanitarianism \& Media, 1900 to the present, Berghahn New York-Oxford: 67-89.

Jackson, A. (2011) Las mujeres británicas y la Guerra Civil española. Universidad de Valencia, Valencia.

Jeger, George (1937) Medical Aid for Spain: The work of the Spanish medical Aid Committee. Spanish Medical Aid Committee, London.

Low, Rachel (1979) "Political Propaganda", The History of the British Film 1929-1939. Films of Comment and Persuasion of the 30 s. George Allen \& Unwin, London.

Mates, Lewis H. (2007) The Spanish Civil War and the British left: political activism and the popular front. London; Tauris Academic Studies, New York. 
McNair, John (1936) In Spain Now! A first-hand Story of the Fight against Fascism and the use of Workers' Power for Socialism. London: Independent Labour Party. Maitland Sara Hallinan collection, Modern Records Centre (MRC), 15X/2/209/99.

Mendlesohn, Farah (2002) Quaker relief work in the Spanish Civil War. Edwin Mellen Press, Lampeter.

Norris Nicholson, Heather (2006) "Shooting in Paradise: Conflict, Compassion and Amateur Filmmaking during the Spanish Civil War”. Journal of Intercultural Studies, 27 (3): 313-330.

Palfreeman, Linda (2012) ;Salud!: British volunteers in the republic medical service during the Spanish Civil War, 1936-1939. Sussex Academic Press, Brighton.

Palfreeman, Linda (2014) Aristocrats, Adventurers and ambulances. British Medical Units in the Spanish Civil War. The Cañada Blanch -Sussex Academic studies on contemporary Spain, Brighton.
Paulmann, Johannes (2019) Humanitarianism \& Media, 1900 to the Present. Berghahn, Oxford.

Preston, Paul (2008), We Saw Spain Die: Foreign Correspondents in the Spanish Civil War. Constable and Robinson, London.

Ryan, Trevor (1986) Labour and the media in Britain 1929-1939. A study of the attitudes of the labour movement towards the new media, film and radio, and of its attempts to use them for political purposes. Thesis Leeds University, School of History.

Sánchez Alarcón, Inmaculada (2009) La Guerra Civil española y el cine francés. Amelia Romero, Barcelona.

Sánchez Dura, Nicolás (2007) Todos muertos. La guerra total imaginada. Guerra en la ciudad, 1936-1939. Colección MonrealCabrelles. Diputación de Valencia, Valencia.

Vance Kepley, Jr. (1983) “The Worker's International Relief and the Cinema of the Left, 1921-1935", Cinema Journal 23(1): $7-23$. 